\title{
THE DELAYED DEVELOPMENT \\ OF EARLY BRAZILIAN FINANCIAL \\ HISTORIOGRAPHY, 1889-1930
}

\author{
GAIL D. TRINER * \\ Rutgers University
}

\section{RESUMEN}

Este trabajo presenta un visión panorámica de la evolución de la historiografía económica de la Primera República, para determinar las causas de la demora del desarrollo de las investigaciones sobre la historia financiera interna. Se argumenta que la atencion en los mercados internacionales, prevaleciente en el enfoque de la teoría de la dependencia, tuvo como consecuencia el descuido de la estructura de las finanzas internas. En tiempos recientes, los investigadores han dedicado mayor atención a los enfoques que subrayan el equilibrio entre los factores económicos internos e internacionales, incluyendo el análisis de las redes de distribución y las estructuras institucionales financieras. Esta perspectiva sugiere que, dentro del sector privado, una estabilidad financiera emergió durante la Primera República y que el campo de las finanzas contribuyó positivamente al crecimiento económico, a pesar de las vicisitudes de las finanzas públicas. Estas conclusiones tentativas ofrecen una perspectiva muy diferente sobre la naturaleza del desarrollo económico del Brasil y sugieren nuevas y desafiantes preguntas.

\section{ABSTRACT}

This article offers an overview of the evolution of economic historiography of the First Republic in order to consider why it has taken so long for domestic financial history to gain importance on the research agendas of Brazilian eco-

* I thank Douglas Cole Libby and Maria do Carmo Sartori for their assistance and comments. This article was written during a year as a Fellow at the Bunting Institute, Radcliffe College, Harvard University. 
nomic historians. It contends that the focus of dependency theory on international markets resulted in neglecting the structure of domestic finance. Recently, scholars have turned their attention to approaches that emphasize a balance between domestic and international economic factors, including looking at the distribution networks and institutional frameworks of domestic finance. Evidence from this perspective suggests that within private sectors, financial stability emerged during the First Republic and finance made positive contributions to growth, despite the vicissitudes of public finance. This tentative finding offers a very different perspective on the nature of Brazilian economic development and raises challenging new questions.

The Brazilian First Republic began in 1889 and it soon experienced profound financial crisis. The Republic ended in 1930, almost simultaneously with another financial crisis. Between the «Encilhamento» in the early 1890s, and the Depression of 1929, other financial disruptions occurred frequently. They included the funding loan of 1898; massive bank failures of 1900/01; reforms of 1906 to institute the gold standard, valorize coffee and open the Banco do Brasil; closing the economy from international financial markets from 1914 through 1923; opening central bank facilities in 1923, closing them in 1926; additional debt renegotiations, with house calls from money doctors in 1924 and 1930. These events both shaped and reflected the economic history of the First Republic; and they suggested that all was not well with the financial health of Brazil.

The financial disruptions of the First Republic bore many similarities to the crises that Brazilians have suffered during the last two decades of the twentieth century. Some of the common issues and choices presented by the two periods of financial crises have been: the trade-offs between meeting international obligations and domestic social welfare; the desirability of economic growth generated by participation in global trading systems as compared to internally-supported growth; the stringency of monetary and fiscal policy; shifting areas of comparative advantage and shifting centers of political strength. These apparent similarities heighten the value of understanding this period of Brazilian financial history.

This article offers an overview of the evolution of economic historiography of the First Republic in order to consider why it has taken so long for domestic financial history to gain importance on the research agendas of economic historians of Brazil. Rather than considering the events of financial history ${ }^{1}$,

' For these, see Peláez and Suzigan (1976), Neuhaus (1974) and Topik (1987). Many of the works cited in this article do not focus exclusively on the First Republic; they may 
it explores the effects of the paradigmatic debates on dependency theory from 1960s through the mid-1980s in shaping - and limiting - the direction that research in economic history has pursued. Without doing justice to its diversity and nuance, and even without debating its merits or problems, this article explores the implications of debates on structuralism/dependency for the perspectives and themes of historical research on the Brazilian First Republic $^{2}$. The article contends that the dependentista focus on international markets resulted in neglect of the structure of domestic finance. Recently, scholars have turned their attention to approaches that emphasize a balance between domestic and international economic factors, including looking at the distribution networks and institutional frameworks of domestic finance. Domestic financial history is a late developing, but important, linchpin of economic structure. It offers valuable insight on the institutional and political economy questions of interest to the «new economic historians,» while also exploring the evolution of connections between sectors and regions. Evidence from this perspective suggests that within private sectors, financial stability emerged during the First Republic and finance made positive contributions to growth, despite the vicissitudes of public finance. This tentative finding offers a very different perspective on the nature of Brazilian economic development and raises challenging new questions.

\section{THE EARLY PARADIGM OF DEPENDENCY}

In the 1950s, within the context of post-World War II strategizing to remedy «underdevelopment», a well-articulated economic ideology of structuralism emerged in Latin America. Economists at the United Nations Economic Commission on Latin America (CEPAL), most prominently Raúl Prebisch, dedicated their efforts to resolving the problems of widespread poverty and the slow pace of industrial development in Latin America. They converged on a belief that persistently unfavorable terms of trade disadvantaged commodity-exporting economies in their capacities to accumulate the capital to construct industrial plant. In the contemporary context

consider longer time frames or represent some of the fundamental data construction efforts that also incorporated the time period.

${ }^{2}$ On the roots of the long intellectual tradition in Brazil, see Love (1996, Chaps. 10-12). Haber (1997, Introduction) and Platt (1980, offer strongly stated refutations of Latin American dependency theorists). A very large body of literature supporting and refuting dependency, structuralism and their infinite variants is widely available. 
of economic developmentalism, the policy implications of structuralist thought emphasized self-sufficiency and domestic production, these policies became known as «import-substituting industrialization».

With time, structuralism became politicized and a more extreme version arose - dependency. Dependency theory served as the flash point for much subsequent debate. In the 1960 s and 1970 s dependency theory historicized the structuralist arguments in order to explain deeply entrenched poverty and inequality ${ }^{3}$. Beginning from an assumption of unequal power relations between imperial power and colony (or «core» and «periphery») dependentistas found that Latin American economic development, with its roots in colonial power structures, had become dependent upon, and supportive of the core imperial economies ${ }^{4}$. Using Marxist concepts of imperialism and class formation, dependentistas radicalized structuralist arguments about unfavorable terms of trade in the periphery. They also constructed arguments about the historically entrenched alliances among elites in the center and periphery that inhibited broadly based development for the general populations of peripheral economies.

This became the predominant organizing paradigm for Brazilian economic history (as well as for many other topics), and debating its veracity defined the research agenda of the discipline. Based on intense historical experience with commodity exports, notably coffee and sugar, Brazilian social scientists were major producers and consumers of structuralist/dependency thinking. Scholars wrote new economic history surveys of Brazil fully shaped by the perspective that commodity exports to the imperial - or developed - world had for centuries determined the economic reality that Brazilians faced and defined their structural economic problems. Notably defining this genre, Prado (1945) and Furtado (1959 and 1969) produced seminal works in structuralist theory that came directly from the cepalista efforts. Later, Cardoso y Faletto (1979) offered the most sophisticated interpretation of structuralist theory.

Two assumptions of structuralist/dependency thinking motivated a lack of attention to domestic financial systems ${ }^{5}$. To the extent that finance occupied historians, the attention to global forces focused interest primarily

${ }^{3}$ The intellectual origins of dependency in historicizing structuralism contains its own irony. One of the major theoretical arguments against dependency has been the a-historical and static nature that it ascribes to the condition of dependency.

4 An early and classic exposition is Frank (1967).

5 In one of the earliest bibliographic reviews of First Republican economic historiography simply contains nothing with respect to finance. (Luz 1976). As another example, a study 
on the international capital markets. The assumption of low levels of domestic capital accumulation rendered it uninteresting, even as the assumption remained untested. Secondly, dependentistas (more than structuralists) were pre-disposed to assume that activities of distribution (notably commerce and finance) were «parasitic» in the sense that the activities did not contribute value-added to products, but did contribute, uneconomically, to the wealth of their practitioners. This assumption left unexamined their value in allocating resources.

Structuralist/dependency perspectives were particularly important for understanding the Brazilian First Republic ${ }^{6}$. They gained predominance simultaneously with the years when the passage of time first made historical analysis of the Republic possible. These emerging theories offered an opportunity to explain persistent poverty and inequality. The First Republic offered an especially enticing setting to test for the presence and examine the implications of, dependency. The years of the Republic included the apogee of Brazilian dominance in world coffee markets, massive immigration, the beginning of industrialization, as well as continual tension in capital markets. Dependentistas asserted that during the First Republic relationships of dependency supported the wealth of coffee fazendeiros as well as European and Brazilian coffee merchants. In this view, the same relationships also subsidized the consumption habits of North American and European consumers, caused unsustainable international debt and delayed industrialization. Logic suggests that the global trade and financial relations contributed mightily to structures of wealth and production, justifying the attention devoted to them. However, the central precepts of dependency left the structure and growth of the domestic economy (defining the daily well-being and possibilities for the majority of Brazilians) relatively neglected, and they often characterized Brazilians as recipients rather than agents of their experience ${ }^{7}$.

on «Café e Indústria em Minas Gerais (1870-1920)» offers no discussion on the financial mechanisms by which the two vital sectors intersected (or not). (Lima 1981)

${ }^{6}$ It is important to recognize that examining the implications of dependency often occurred independently of testing for its presence.

7 Certainly, domestic economic circumstances were not totally neglected; but they were largely informed by structuralist theses. Regional, or locally specific, history often explored the importance of the formation of local capitalist markets in the dependency context (Fonseca 1985). One of the more innovative extensions of dependentista perspective was the application of core/periphery dynamics to the development of economic relations between 


\section{EMPIRICAL BASES FOR RESEARCH}

The exigencies of labor-intensive data accumulation and capital-and technology-intensive (in the context of academic research) data analysis posed a barrier to the empirical study of many financial questions. Nevertheless, many of the issues originally raised by dependency (or structuralist) theory were empirical in nature. Efforts both to support and negate structuralism/dependency motivated data collection and empirical analysis. In fact, much research of the 1960 s through the 1980 s was dedicated to accumulating, reconstructing and estimating the size of the historic economy. Scholars constructed time series data for the national product (Haddad 1974b, Contador and Haddad 1975, Villela and Suzigan 1973 and Fishlow 1972), price levels (Lobo 1978, Contador and Haddad 1975 and Haddad 1974b), money supply and its components (Neuhaus 1974 and Peláez and Suzigan 1976), and international debt (Abreu 1985 and Peláez and Suzigan 1976). Goldsmith (1986) compiled these studies in order to construct a comprehensive analysis of the effects of long-term Brazilian inflation. The first projects to document the size and nature of capital markets and banks also emerged in these years (Levy 1977 and 1972). These projects were painstakingly compiled. They demonstrated that calculations of the levels of economic activity were very sensitive to methodology; parallel time series could be used to support contrasting conclusions. Depending on the time series selected, one could support a wide variety of conclusions about the economic trajectory of Brazil. However, all of the measures pointed to extreme rates of fluctuation in all aspects of economic activity and policy during the First Republic.

The publication in 1987 of the first edition of Estatísticas Historicas do Brasil (Brasil, IBGE 1987; volume 3, Séries Estatisticas Retrospectivas) accumulated the results of the macro-level times series. It included an encompassing analysis of their methodological strengths and weaknesses ${ }^{8}$. This exercise, undertaken with the participation of a wide variety of economists and economic historians, seemed to indicate acceptance of existing

regional markets to explain the formation and strength of economic predominance in São Paulo (Cano 1977).

${ }^{8}$ The publication of Estatísticas Históricas was the first time the results of historical economic activity had been centrally accumulated and assessed. While much of the data generated for the equally significant Annuário Estatistico (Instituto Brasileiro de Geografica e Estatística. Conselho Nacional de Estatística 1939-40) remained in place, they were supplemented by much subsequent academic research. 
data accumulation and estimation. Much remains uncertain with respect to precise growth rates, price levels, and sectoral composition of the economy. But, the publication of this volume connoted that many economists did not anticipate further rigorous refinement to resolve these ambiguities. More recently, empirical data accumulation efforts have accommodated the analytical requirements of specific questions, rather than reconstructing macroeconomic time series. For example, recent projects that have entailed new data accumulation include: imports of capital goods to assess the pattern of industrialization (Suzigan 1986), the social benefits of infrastructure construction (Summerhill 1995, on railways), activity on stock markets and in banks (Hanley 1995 and Triner 1994), industrialization and capital formation in the textile industry (Haber 1991a and 1991b). Increasingly sophisticated analyses of prices (Catão 1992b), business cycles (Catão 1990a) and exchange rates (Franco 1986) have arisen from other studies.

\section{THE EVOLUTION OF RESEARCH FINDINGS}

The tensions between change and continuity in many aspects of social organization during the First Republic are well documented. Simultaneously with the uncertainties of transition from Empire to Republic and from slave to wage labor, new political oligarchies used the dynamics of urbanization, migration, industrialization, and military and popular uprisings to slowly construct power bases ${ }^{9}$. The consensus within political historiography of a weak state and poorly articulated emerging interest groups had its analog in the economic historiography. Much economic research has found that the powerful coffee sector, slowly forming industrial and commercial interests, and the economic activities of state formation combined in fluid manners to forward their interests (Topik 1987, Fritsch 1988 and Baer 1995). The production and trade of coffee remained the strongest private economic sector throughout the First Republic ${ }^{10}$. However, industrialization advanced with sufficient dynamism to anticipate its competition with the coffee sector as an important means of generating wealth ${ }^{11}$. Within this context, traditional portrayals of the economic history of the Republic

\footnotetext{
${ }^{4}$ For an overview of First Republican political history see Carone (1988).

${ }^{10}$ Fishlow (1980, p. 104), however, states that by 1930 coffee production only accounted for $10 \%$ of Brazilian national production.

"Luz (1978 [1960]) traces interest in developing industrial capacity to the mid-nineteenth century; but the first results only became apparent in the early twentieth
} 
have fallen into two overlapping categories. First, much effort was devoted to determining whether Brazilian participation in global markets, especially for coffee, supported or inhibited industrialization. The history of economic policy has been the second major category of the research; monetary policy had pride of place in this research. Both emphases reflected logical concerns about the Brazilian economy and merit the attention they received. The dependency debates, or less contentiously, the consideration of the role of international influence, defined both trajectories of research.

Challenges to the structuralist/dependency paradigm arose early on both theoretical and empirical grounds. Dependency theory, with its focus on power relations and wealth distribution, often carrying normative judgements, met with alternative analyses that emphasized total wealth and growth. The historical experience with structural economic change, defined narrowly as industrialization, provided a major testing of these ideas. In it most simplified form and using the Brazilian First Republic as an important case study, the question was whether industrialization in the periphery occurred primarily as the result of external shocks that disrupted trade flows or was favorably associated with commodity exports ${ }^{12}$. Dependency theorists hypothesized that external shocks (such as war or Depression in the core countries) stimulated development. Disruptions in both the supply of industrial goods from «core» economies and the demand for commodities (primarily coffee) from the periphery forced Brazilians to break original trading relationships. As a result, external shocks caused Brazilians to rely more heavily on, and thus stimulated, domestic production of increasingly diverse and sophisticated goods. Support for this argument in the Brazilian First Republic, developed most prominently by Furtado, Prado and Fishlow focused on the increased volume of industrial production during World War I, the Depression and perhaps the Encilhamento (Furtado 1993 [1959], Prado Jr. 1993 [1945] and Fishlow 1972). During these years, because of events outside of their control Brazilians did not have access to global markets, and the volume of industrial production increased.

The alternative argument of «export led growth» countered that increased production during these shocks simply utilized previously idle capacity. This argument found that the domestic capital formation that made indus-

century. Baer (1995) is the most widely known analysis that dates the onset of significant industrialization later than the First Republic.

${ }_{12}$ With time, the formulation of these questions in terms of the types of linkages that industrialization created gave them a less normative framework (Hirschman 1981). 
trial production possible had occurred under earlier conditions of prosperous commodity export markets. Supporters of export-led-growth models focused on the accumulation and re-allocation of wealth generated by the prosperity of the coffee sector during much of the First Republic (Dean 1976, Peláez and Suzigan 1976, Leff 1982 and Suzigan 1986). This interpretation challenged the negative judgements of dependency by suggesting that exploitation of its comparative advantage in coffee production maximized Brazilian wealth. Further, it found that the wealth generated by participation in global markets propelled subsequent development within Brazil.

Monetary history and monetary policy offered another perspective for viewing the effects of international markets on the domestic economy because the relationships between capital flows, currency value and money supply mediated the intersection between domestic and international sectors. The judgements of monetary historians countered dependentistas, though they were more subtle than some of the overtly politicized dependency agendas. On the criteria of traditional monetary analysis, in the style, and under the direction, of the «Chicago School», Neuhaus delineated the trajectory of Brazilian monetary history. This analysis found that more consistent application of orthodox monetary policy, maintaining full currency convertibility and a fixed exchange rate, would have resulted in better accommodation with the demands of the domestic and international sectors during the 1890s and 1920s because of its anticipated ability to stabilize domestic prices and consolidate public sector financial rectitude (Neuhaus 1974). Nevertheless, insufficient flexibility in abandoning these concepts deepened the hardship of the World War I years. This analysis accepted the interpretations of financial experience rooted in international markets; but it did not support structuralist policy predisposition for withdrawal from participation in those markets.

With a more «developmentalist» perspective, Peláez and his colleagues built a broadly-based argument against the application of dependency to Brazilian history. Using neo-classical methods to explore the terms of trade, he concluded that nineteenth century coffee production was far from an example of a dependent relationship for Brazilians (Peláez 1976b) and that coffee price supports in the First Republic slowed industrialization, because of their effects in eroding Brazilian comparative advantage in the product (Peláez 1971a) ${ }^{13}$. His analysis of monetary history supported the

${ }_{13}$ This perspective has since been challenged, most prominently by Suzigan (1986), who found that coffee valorization sustained domestic incomes and consumption. 
conclusions that export led growth theories substantially explained the Brazilian experience and the policy efforts that limited the ability of Brazilians to maximize their comparative advantage in agricultural exports diminished their long-term welfare (Peláez and Suzigan 1976) ${ }^{14}$. These findings led Peláez to conclude that sustained efforts to maintain monetary orthodoxy represented long-term mismanagement and they contributed significantly to deeply-entrenched poverty (Peláez 1971b).

Other early work on monetary history focused on specific experience, such as the financial market collapse of the 1890 s, the Encilhamento. These studies addressed the dependency debate directly. Some authors categorized these early crises as financial failures resulting from overly expansive monetary policy and hollow monetary speculation on money and equity markets, with disastrous results on exchange rates, prices and income levels (Lobo 1976, Levy 1977 and 1980 and Goldsmith 1986). Others viewed the disruptive speculative period, with devalued currency and limited access to international capital markets, as motivation for initiated import-substituting industrialization (Fishlow 1972 and Versiani 1980) ${ }^{15}$.

The focus on money supply and monetary policy left two important gaps in connecting these endeavors to our understanding of Brazilian reality. Both gaps are particularly important for the history of the First Republic. First, with economic growth and shifts in the importance of emerging economic sectors, questions about the demand for money became important, and they remained largely ignored. The second problem of the monetary scholarship was that it implicitly accepted the underlying premise of monetary theory: that the primary role of monetary policy was to manage price stability. Most findings support, instead, the interpretation that the Brazilian monetary policy was less a tool to manage prices than to manage the finances of the Brazilian government (Topik 1987 and Fritsch 1988). Other issues related to financial markets have received lesser consideration. Interest in banks has been limited to their contribution of deposits to the money supply. Such important issues as their roles in capital formation

${ }^{14}$ In a later critique, Abreu observed that Peláez often assessed the intent of policy, rather than its effects, to derive conclusions about the impact of global markets (Abreu 1990).

15 Levy (1980) adds the interesting and appropriate caveat that these «revisionist» interpretations of the Encilhamento, as a period of capital formation (and re-formation) rely on studies only of the textile industry. Respondents would, of course, reply that textiles were the largest manufacturing industries of the time; their experience would be the most important for determining the impact of the Encilhamento on industrialization. 
or commercial development and their auxiliary function for public finance were not rigorously explored.

Exploration of organizations and institutional structures partially addressed some of these lacunae ${ }^{16}$. A sparse early tradition of business history studied specific financial organizations ${ }^{17}$ and produced detailed narratives that maximized the seeming importance of their subjects within the public sector (Azevedo and Vieira Lins 1969, Fontenla 1965 and Pacheco's 1973 four volumes covered the history of the Banco do Brasil up to 1872). Joslin's (1963) history of the Bank of London and South America was virtually the only work to focus on the operation of a bank with exclusively private sector concerns. Although its focus on Brazil was limited (and it did not engage the dependency debate), this was the first business history of a bank operating in Latin America to address institutional issues. Surprisingly, given the dependency debates, other works in the early tradition of business history considering foreign commercial banking did not appear subsequently.

A small body of literature looked at the histories of specific organizations and their role in public policy. By its nature, this body of work was often regional in nature. Most notably, in separate theses, Costa (1988 and 1978) explored the dynamics of state-level politics in the formation of two major state banks, Banespa in São Paulo and Crédito Real in Minas Gerais. These banks formed the basis for the government-owned long-term development finance banks, at the state level. The two theses provided insight on the entry of state level governments into banking. By the time that he wrote about state ownership of Banespa and its evolution into a public sector development bank, Costa explicitly situated the organization of a state-owned development bank in a structuralist context more than in his arguments on Crédito Real. Later, Lagemann (1985) emphasized the organizational history of Banco Pelotense; and this is the only work on Rio Grande do Sul to allude to the otherwise unknown financial political economy of that important state prior to Getúlio Vargas' regime. While these local studies employed structuralist perspectives, they did not develop a unifying theme.

Beyond these early organizational histories, research during the 1970 s and 1980 s slowly began to illuminate institutional structures within the

${ }^{16}$ I do not consider here the extensive political analysis and policy prescriptive work of the First Republic. See Saes (1995, pp. 64-66) for a listing of the most influential of these.

17 Sometimes, the organizations commissioned their histories to be documented, causing the historian to be cautious about their uses. 
financial system. Cano (1977) pursued research on the problems of market formation and the production and distribution of goods on a national scale. Using different arguments, Leff (1982) and L.C. Prado (1991) identified the weakness of domestic market formation as a significant barrier to development in the nineteenth century. Cano's work on the early twentieth century was thematically analogous to the research on the nineteenth century, though not compatible with many of their conclusions. Cano moved questions of dependency and core/periphery relationships to the regional level in order to explain the decisive concentration of industrial development in São Paulo simultaneously with its apogee as the center of coffee wealth during the First Republic.

Taking these issues directly into the financial sphere, in an ambitious master's thesis, Bielschowsky (1975) tried to explore the distributive effects of banking among the real sectors of the Brazilian economy. This paper offered the first articulation that the banking system redistributed resources from agriculture to industry. It arrived at the (seemingly paradoxical) conclusion that banking-induced redistribution among sectors concentrated, rather than diversified wealth among regions and individuals. Without sufficient empirical data, it was difficult to maintain the argument that inflation was the mechanism that motivated concentration. Further, Bielschowsky situated this process in the 1930 s, even though he finds that significant bank expansion began in the 1920 s. Nevertheless, this work offered an insight that has been left undeveloped for two decades. The most comprehensive advance in accumulating the empirical data of financial history came from Levy's work. Although the early research did not receive wide distribution or see book form (only the História da Bolsa de Valores do Rio de Janeiro (1977) was published), it advanced the empirical body of evidence and the understanding of organizational dynamics that served as a point of departure for further monographs.

\section{EMERGING PERSPECTIVES ON DOMESTIC FINANCIAL HISTORY}

By the 1980 s, both political and scholarly trends mitigated against the continuing predominance of structuralist/dependency research. The seeming failure of state-managed economies and the re-emergence of «globalism» in the political sphere coincided with the emergence of cultural 
history to push questions of economic history, and notably, dependency, to the back of many research agendas ${ }^{18}$. At least as importantly, the cumulative effects of the specific tests for dependency in the First Republic called into question its relevance in explaining economic history. The agility displayed by the theory to explain circumstances in any realm of historical experience seemed to dilute its applicability to any specific question (Haber 1997, Introduction) ${ }^{19}$. Finally, with the re-establishment of civilian governance after the years of military rule, the formulation and implementation of economic policy gained new focus. New ideas have been slow in emerging from, or penetrating into, questions of First Republican finance. Nevertheless, new insights from growth theory and the new institutional economic history, with its interdisciplinary focus in political economy, yield findings that promise to deepen our understanding Brazil's financial past.

As is usually the case, recent research builds upon, more than it discards, earlier findings. With the foundation of the earlier work, scholars have begun to take more critical perspectives on the importance of international markets and the importance of domestic circumstance in determining economic well-being. Much of the economic history written in the past decade has linked international flows to the domestic economy. As a notable example, Suzigan's (1986) innovative assessment of machinery exported from industrialized countries to Brazil linked money, coffee and industry to demonstrate that (with a notable declining trend from 1914), growth and industrialization were positively related to the prosperity of the agricultural export (coffee) sector. The fluctuation of demand and prices for Brazilian exports, the import component of industrial manufactures and the state's debt servicing requirements were the mechanisms transmitting the effects of the international financial environment to the domestic setting. This transmission most immediately occurred through value of the currency (the exchange rate). Therefore the crucial effect of monetary policy on the exchange rate gave the state an avenue into the private-sector economy. Suzigan's notable contribution, beyond the elegant summary of industria-

${ }^{18}$ As an indication of the decline in economic history within Brazil, a search of national and regional journals for the period from 1996 to mid-1998 produced only eleven articles that in any way impinged on economic aspects of the First Republic. Of these, one raised questioned of finance. (Cerqueira and Simones 1997). The published proceedings of the first and third Congressos Brasileiros de História Econômica contain one paper each that specifically address finance during the First Republic (Suzigan and Szmrecsanyi 1996 and Triner 1996a). I will not address here whether the economic and historiographic trends may be causally related to each other. I thank Maria do Carmo Sartori for this research.

${ }^{19}$ I thank Alan Dye for applying the term «agility» to dependency theory. 
lization theories and careful empirical research, was to demonstrate the mediation of exchange rates and economic welfare through monetary policy.

Monetary policy has also considered more explicitly the connections between the public and private sectors in recent years. In the most sophisticated and subtle work on the Encilhamento, Franco (1987) melds political economy and monetary economics. Beginning with the accepted premise that monetary reform in 1890 was an economic result of (and response to) the abolition of slavery, the new republican government recognized the need to create monetary mechanisms to accommodate a wage-based economy. These reforms allowed for expansive banknote issue, thus reinforcing the process of industrialization through the expansion of credit associated with banknote issuance. Based on monetary data and political arguments, Franco finds that the financial collapse of the early 1890 s and the subsequent closing of Brazil's access to international capital markets generated domestic growth and innovation in the productive sectors. In this view, the Encilhamento may have been a failed exercise in state-building and government centralization (notably of banking, through note-issuance regulation.) Nevertheless, its trends were toward the «modern,» and the state internalized the lessons learned from the experience, as demonstrated by the future uniform source of note issuance. Although it failed, monetary expansion had been intended to support economic growth in the state's first active attempt at overall economic management and relegated access to international finance to second order importance.

Franco's work on the Encilhamento belongs to a body of work originating at the Pontifícia Universidade Católica (PUC) of Rio de Janeiro in the 1980s that revised understandings of economic policy during the First Republic. Franco (1987), Topik (1987) and Fritsch (1988) explicitly challenged the «liberal» portrayal of the Brazilian state during the First Republic. They found an actively interventionist state that used monetary policy as iis most effective medium for influencing economic flows. Earlier studies on the protection accorded to industry as a result of tariff policy by Versiani (1980 and 1984) first raised the thesis of effective (if unintended) government intervention in the private sectors. The PUC group extended that reasoning to the realm of monetary policy, and accorded it significantly enhanced importance. Topik demonstrated the active intervention of the State through the financial system and the use of the Banco do Brasil to manage domestic credit in support of international borrowing and exchange rate goals. Fritsch took the argument somewhat further, to what might be termed a neo-dependentista conclusion, suggesting that the 
demands of the international capital markets dictated the limits of monetary independence for republican governments with respect to management of exchange rate and currency convertibility. Fritsch also emphasized that external policy intervention could equally affect fiscal policy. These arguments challenged earlier reliance on the influence of coffee producers, and their opposition to other economic agents, as the motivation for policy. They assigned a sui generis role to the state, even while recognizing the connection of monetary policy with the three coffee valorization programs of the First Republic. Though these works have not yet been subjected to explicit challenge, they shed new light on institutional aspects of economic policy making and state-building. They also provide counter-balance to the weight traditionally accorded the coffee sector in discussions about Brazil's experience with the international economy and attach more subtle political dimensions to monetary policy (especially the fragility of Brazilian adherence to the gold standard from 1906 to 1914 and the attempts again from 1923).

These reconsiderations of monetary policy leave some surprising gaps in the financial historiography of the First Republic. For example, any possible connection between the Brazilian Encilhamento and the 1890 Barings Crisis in Argentina, initiating foreign capital flight from most debtor countries, during (approximately) the same years remains for future work to expose. In another neglected field, the Montagu Mission of 1924 is the only Brazilian experience with «money doctors» that scholars have analyzed (Fritsch 1980 and 1988). This work takes the view that international financial «experts» imposed excessively contractionary orthodox reforms on Brazilian fiscal and monetary policy as a condition for access to London capital markets in 1924. Analogous external prescriptions for reform to support international borrowing in 1898 (the Refunding Loan) and 1930 (the Niemeyer Mission) also deserve attention. The inability or unwillingness of the new Vargas government (the «Revolution of 1930») to abide by the Niemeyer recommendations culminated in the debt payment moratorium of 1932. This episode has received surprisingly little attention from economic historians. Further research may suggest alternative perspectives on the financial crises and the roles of money doctors. The history of these critical intersections between international finance and domestic economic cycles would provide insight on the nature of financial «crises» and the mechanisms by which international finance affected the Brazilian economy.

The end of the Republic coincided with a complicated financial crisis of domestic and international dimensions. From 1927, the Brazilian eco- 
nomy was in severe recession; the global Depression began in 1929 and the Revolution of 1930 followed immediately. In 1932, the federal Treasury declared a moratorium on international debt payment obligations. While we know that output suffered significantly ${ }^{20}$, we also know that the consequences of the Depression were mild (in internationally comparative terms), presumably because of countercyclical policies (Abreu 1990, Fishlow 1972, and Furtado 1963 [1959]). Econometric analysis offers support to the interpretation of the Depression that government intervention was needed to minimize this external shock (Cardoso 1981). However, Gupta (1997) offers new evidence, with firm level data of capital goods to suggest a harsher experience with the Depression. We also know that banking and the securities exchanges reflected economic decline during the years of external shocks, even if we do not know their directions of causality (Levy 1977 and Triner 1994). These fragments of information have not been integrated to come to an understanding of the distinct effects of the global Depression, political regime change and domestic recession.

\section{PRIVATE SECTOR FINANCE}

The revision of policy history that occurred in the 1980s sustained one of the notable aspects of the earlier monetary history: it only weakly considered the impact of domestic finance on the economy. A wider historiography about finance as a motor of economic development had very little application within Brazil ${ }^{21}$. Early work by Peláez (1975 and 1976a) had summarily dismissed its systemic importance. Although the presumption of deficiencies in domestic credit markets runs through the historiography, previous paradigmatic debates about the legitimacy of dependency have not left room to document or consider the nature of these deficiencies or to explore their implications. The traditional organizational and political histories of state banks also neglect the institutional role of financial agents.

Saes' (1986) careful work, with individual bank data, delineated the dynamic interconnection between banking, coffee and industry in São Pau-

${ }^{20}$ Even with this unambiguous conclusion, the exact nature of the decline in production remains somewhat mysterious (Haddad 1974a, Contador and Haddad 1975 and Versiani 1980).

${ }^{21}$ Gerschenkron (1962) and Cameron (1967) are the classic works of this genre, with respect to European economic history. 
lo. While making an argument about financial formation in the consolidation of capitalist relations of production, Saes examined the distinctions between foreign and domestic, and rural and urban, banking in São Paulo during the «golden years» of its coffee production. This study of the crucial state in the Brazilian federation demonstrated the consolidation of a local banking system, from its antecedents in personalized credit, within the confines of economic and political pressures.

A recent body of research goes beyond these questions to focus on the fundamental institutional mechanisms of the financial sector. Levy (1994, posthumous publication of her 1988 tese) pioneered this effort with an examination of the change of corporate organization from small, privately-held companies to limited liability, publicly-traded incorporation in Rio de Janeiro. Since Levy's research, this trajectory has seen more of its practitioners in the United States, where questions of institutions and the nature of growth have gained attention, than in Brazil ${ }^{22}$. Banks and securities exchanges both reflected and responded to cyclical fluctuation in predictable and efficient manners. Examining the efficiency of capital markets in aiding capital formation, Haber has found that capital markets efficiently accommodated capital formation and reflected corporate profitability in the most important early manufacturing industry, textiles (Haber 1991a and 1997) ${ }^{23}$. Hanley (1998) continues in this vein, demonstrating that the São Paulo Bolsa de Valores dynamically served to accumulate Brazilian capital to substantially aid the formation of industrial, commercial and infrastructure firms. This work convincingly finds that, at the dynamic center of economic growth, financial institutions innovated to support growth. In the less dynamic market of Rio de Janeiro, limited liability, publicly registered and traded corporations also became an important form of corporate organization, but dynamic trading of share ownership grew slowly (Triner 1994). This finding suggests that the many of the advantages

22 The prevalence of this work in the United States reflects interests that have arisen among economic historians there, without regard to locale of research. The theoretical framework of Douglass North provides the grounding for much of this research (North 1990 and 1981). One of the attractions of the «new institutional economic history» is that it offers some hope of addressing the heretofore mystifying question of the difference between "developed" and underdeveloped." The relative scarcity of this approach within the research community in Brazil reflects the current scarcity of economic research of any kind, and perhaps continuing resistance to abandoning structuralist/dependency arguments.

${ }^{23}$ Versiani (1984) stressed, however, that textiles were an a-typical industry in the inter-war years. Haber's work also provides the first glimpse of an otherwise completely ignored field: comparative financial development. Haber finds that Brazilian capital markets were more developed than those of Mexico and less so than those of the United States. 
of corporate organization -with respect to transferring ownership and risk in a de-personalized manner - materialized only with difficulty. From another neglected perspective of capital formation, Suzigan and Szmrecsányi (1996) begin to document the initial phases of foreign direct investment (as distinct from portfolio investment) during the First Republic ${ }^{24}$.

On-going empirical research and institutional investigations suggest that during the First Republic banks also supported the modernizing trends that typically focus on industry. They show that banks managed the risks of losses against the desire for profits in prudent, conservative and increasingly sophisticated manners. Banks supported economic growth and diversification, largely through the indirect route of providing working capital for ongoing concerns, thus freeing wealth for entrepreneurial long-term capital formation. Works on the role of banks in domestic capital formation in São Paulo and on publicly-chartered banks throughout Brazilian financial centers challenge earlier skepticism about the ability of banks to respond to their economic environments (Hanley 1997 and Triner 1996b). Most recently, Marques (1998) has explored the ability of banks to link innovative economic activity among various sectors through the case studies of specific banks in Rio de Janeiro. These works further our understanding of the formation and operation of banks. In doing so, they also further our understanding of sectoral and regional market formation, which was one of the important «modernizing» features of the First Republic economy.

These recent studies on banks and securities exchanges arrive at the somewhat surprising conclusion that financial institutions within the domestic private sector were relatively successful, efficient, and dynamic, while also conservative. These institutions accumulated and allocated domestic capital to an impressive variety of innovative business ventures in manners that were both safe and profitable. If this body of work on domestic financial markets is to stand the test of time, it will need to resolve a number questions that address the seeming disparity between public and private sector experience: Were private sector financial mechanisms and institutions, in fact, «successful»? If so, how did their success relate to fluctuations and (perhaps) failures of public finance in international capital markets? Were there chronological or institutional limits of success in private financial sectors, such that they may not have been transmitted to an ever-increasing circle of economic agents? If private sector finance was successful, how

${ }^{24}$ Serious consideration of foreign direct investment had previously considered a later period and was framed in the context of extending dependency arguments to allow for industrialization and «dependent development» (Evans 1979). 
did the public sector retain such a large share of the banking system? Further investigation of institutions and political economy can address these issues - or they may cause subsequent researchers to wish for a revival of the earlier suppositions about the external imposition of disadvantage.

However, further understanding of these issues has a large potential reward. They can provide insight on the underlying mechanisms by which subsequent political regimes constructed tools of economic management and state ownership with fundamental long-term implications for the structure of the Brazilian economy and on the nature of domestic market formation. Understanding these questions in the context of the First Republic can also illuminate for the «money doctors» at the end of the twentieth century the implications of their prescriptions as global markets continue to transmit their variability to economic agents in Brazil.

\section{REFERENCES}

Abreu, M. de Paiva (1985), «A Dívida Pública Externa do Brazil, 1824-1931», Estudos Econômicos (Instituto de Pesquisas Econômicas, Universidade de São Paulo)15(2):167-89.

- (1990), «Crise, Crescimento e Modernização Autoritária: 1930-1945», in A Ordem do Progresso: Cem Anos de Politica Econômica Republicana, 1889-1989, 73-104, Rio de Janeiro, Campus.

Azevedo, T. d., and Vieira Lins E. (1969), História do Banco da Babia, 1858-1958, Rio de Janeiro, Liv. José Olympio Editóra.

BAER, W. (1995), The Brazilian Economy: Growth and Development, 4th Westport, Conn.: Praeger.

BIELSCHOWSKY, R. A. (1975), «Bancos e Acumulação de Capital na Industrialização Brasilieira - Uma Introductória (1935-1962)», Tese de mestrado. Brasilia: Universidade de Brasilía.

Brasil, Instituto Brasileiro de Geografia e Estatística (1987), Estatísticas Históricas do Brasil: Séries Econômicas, Demográficas e Sociais 1550 a 1985, vol. 3, Rio de Janeiro.

- Conselho Nacional de Estatística (1939-40), Annuário Estatístico do Brasil, Ano $\mathrm{V}$, Rio de Janeiro.

CAmeron, R. E. (ed.) (1967), Banking in the Early Stages of Industrialization; a Study in Comparative Economic History, with the collaboration of Olga Crisp, Hugh T. Parrick and Richard Tilly, New York: Oxford University Press.

CANo, W. (1977), Raizes da Concentração Industrial em São Paulo, Corpo e Alma do Brasil, 53. Rio de Janeiro: DIFEL/Difusão Editorial, S. A.

Cardoso, E. A. (1981), «The Great Depression and the Commodity-Exporting LDCs: The Case of Brazil». Journal of Political Economy, 89(6):1239-50, 6. 
Cardoso, F. H., and FaletTo, E. (1979) [1971]. Dependency and Development in Latin America, Trans. Marjory Mattingly Urquidi, Berkeley: University of California Press.

Carone, E. (1988), A Primeira República (1889-1930), 4th ed., Rio de Janeiro: Editora Bertrand Brasil.

Catão, L. A. (1990), «Constraints to Balanced Long-Term Growth: The Cases of Brazil and Mexico, 1870-1913», University of Sāo Paulo and PUC-Rio de Janeiro, May.

- (1992), «A New Wholesale Price Index for Brazil During the Period 1870-1913», Revista Brasileira de Economia, 46(4, Oct.-Dec.): 519-33, 4.

Cerqueira, H. E. d. G., and Simōes, R. (1997), «Modernizaçāo e Diferenciação Econômica em Belo Horizonte», Varia Historia, 18 (Sept.): 443-63, 18.

Contador, C. R., and Haddad, C. L. (1975), «Produto Real, Moeda e Preços: A Experiência Brasileira no Período 1861-1970», Revista Brasileira de Estatística, 143(36):407-40, 36 .

DA Costa, F. Nogueira (1978), «Bancos em Minas Gerais (1889-1964)», Tese de mestrado. Brasil: Universidade Estadual de Campinas.

- (1988), «Banco do Estado: O Caso Banespa», Tese de doutoramento. Universidade Estadual de Campinas.

DEAN, W. (1969), The Industrialization of São Paulo, 1880-1945, Institute of Latin American Studies, monograph, n. ${ }^{\circ} 17$, Austin: University of Texas Press.

Evans, P. B. (1979), Dependent Development: the Alliance of Multinational, State, and Local Capital in Brazil, Princeton: Princeton University Press.

Frshlow, A. (1972), «Origins and Consequences of Import Substitution in Brazil», in International Economics and Development: Essays in Honor of Raul Prebisch, Luís Eugenio di Marco and Raúl Prebisch, 311-65. Economic Theory and Mathematical Economics. New York: Academic Press.

- (1980), «Brazilian Development in Long-Term Perspective», The American Economic Review, 70(2, May): 102-08.

FonseCA, P. C. D. (1985), «A Transição Capitalista no Rio Grande do Sul: A Economia Gaúcha na Primeira República», Estudos Econômicos, 15(2, May-Aug.): 263-89.

Fontenla, V. P. (1965), História dos Bancos no Brasil, Rio de Janeiro.

Franco, G. H. B. (1986), «Taxa de Câmbio e Oferta de Moeda: 1880-1897: Uma Arálise Econométrica», Revista Brasileira de Economia, 40(1, Jan.-Mar.): 63-88.

- (1987), Reforma Monetária e Instabilidade Durante a Transição Republicana, 2d ed., Rio de Janeiro: Banco Nacional de Desenvolvimento Econômico e Social.

FrANK, A. G. (1967), Capitalism and Underdevelopment in Latin America: Historical Studies of Chile and Brazil, New York: Monthly Review Press.

FrrTsCH, W. (1980) [1924], Pesquisa e Planejamento Econômica, 10(3, Dec.): 713-44.

- (1988), External Constraints on Economic Policy in Brazil, 1889-1930, Pittsburgh: University of Pittsburgh Press.

FurtadD, C. (1963) [1959], The Economic Growth of Brazil: A Survey from Colonial to Modern Times, Trans. Ricardo W. de Aguiar and Eric Charles Drysdale, Berkeley: University of California Press. 
- (1986), Economic Development of Latin America. In Promise of Development: Theories of Change in Latin America, ed. Peter F. Klarén and Thomas J. Bossert, 124-48, Boulder, Colo.: Westview Press.

- (1993) [1959], Formaa̧ão Econômica do Brasil, 40th ed. São Paulo: Brasiliense.

GersChenKRon, A. (1962), Economic Backwardness in Historical Perspective, Cambridge, Mass.: Harvard University Press.

GoldSMrth, R. W. (1986), Brasil 1850-1984: Desenvolvimento Financeiro Sob um Século de Inflação, São Paulo: Banco Bamerindus e Ed. Harper Row do Brasil. GuptA, B. (1997), The Great Depression and Brazil's Capital Goods Sector: A Re-examination, Revista Brasileira de Economia, 51(2, april-june).

HABER, S. H. (1991a), Industrial Concentration and the Capital Markets: Brazil, Mexico and the United States, 1840-1930. Joumal of Economic History, 51(3, Sept.): $559-80$.

- (1991b), Lucratividade Industrial e a Grande Depressão no Brasil: Evidências da Indústria Textil de Algodão, Estudos Econômicos, 21(2, May-Aug.): 241-70.

- (1997), «Financial Markets and Industrial Development: A Comparative Study of Governmental Regulation, Financial Innovation and Industrial Structure in Brazil and Mexico, 1840-1930», in How Latin America Fell Bebind: Essays on the Economic Histories of Brazil and Mexico, 1800-1914, ed. S. Haber, 146-78. Stanford CA: Stanford University Press.

Haddad, C. L. (1974a), «Crescimento Econômico do Brasil, 1900-1976», in Economia Brasileira: Uma Visão Histórica, Paulo Neuhaus, 21-44. Rio de Janeiro: Campus Ltda.

- (1974b), «Growth of Brazilian Real Output 1900-1947», Ph. D. Diss. University of Chicago.

Hanley, A. G. (1995), «Capital Markets in the Coffee Economy: Financial Institutions and Economic Change in Sāo Paulo, Brazil, 1850-1905», Ph. D. Diss. Palo Alto CA: Stanford University.

- (1997), «Banking Activity and Bank Profitability: São Paulo, 1884-1920», presented at University of Illinois-Urbana Champaign.

- (1998), «Business Finance and the São Paulo Bolsa, 1886-1917», in Latin America and the World Economy in the Nineteenth and Twentieth Centuries, ed. J. H. Coatsworth and Alan M. Taylor. Cambridge: Harvard University Press.

Hirschman, A. O. (1981), «A Generalized Linkage Approach to Development, with Special Reference to Staples», in Essays in Trespassing: Economics to Politics and Beyond, ed. Albert O. Hirschman, 59-97. Cambridge, Eng.: Cambridge University Press.

Josuin, D. (1963), A Century of Banking in Latin America; to Commemorate the Centenary in 1962 of the Bank of London E South America Limited, New York: Oxford University Press.

Lagemann, E. (1985), O Banco Pelotense e O Sistema Financeiro Regional. Série Documenta; 19. Porto Alegre, RS: Mercado Aberto.

LeFF, N. H. (1982), Underdevelopment and Development in Brazil, 2 vols, London; Boston: Allen \& Unwin.

LevY, M. B. (1972), História dos Bancos Comerciais no Brasil (estudo preliminar), Rio de Janeiro: IBMEC. 
- (1977), História da Bolsa de Valores do Rio de Janeiro, Rio de Janeiro: IBMEC.

- (1980), «O Encilhamento», in Economia Brasileira: Uma Visāo Histórica, Paulo Neuhaus, 194-204. Rio de Janeiro: Campus.

- (1994), A Indústria do Rio de Janeiro Através de Suas Sociedades Anônimas: Esboços de História Empresarial, Coleção Biblioteca Carioca. Rio de Janeiro: Editora UFRJ: Prefeitura da Cidade do Rio de Janeiro, Secretária Municipal de Cultura, Departamento Geral de Documentaçāo e Informação Cultural, Divisāo de Editoração.

Lima, J. H. (1981), Café e Indústria em Minas Gerais (1870-1920), Petrópolis: Vozes. Lово, E. M. L. (1976), «O Encilhamento», Revista Brasileira de Mercado de Capitais, 2(5, May-Aug.): 261-301.

- (1978), História do Rio de Janeiro: Do Capital Comercial ao Capital Industrial e Financeiro, 2 vols, Rio de Janeiro: IBMEC.

Love, J. L. (1996), Crafting the Third World: Theorizing Underdevelopment in Rumania and Brazil, Comparative Studies in History, Institutions, and Public Policy. Stanford, Calif.: Stanford University Press.

Luz, N. V. (1976), «A História Econômica do Brasil no Período de 1830-1930 -Abordagens e Problemas: Um Ensaio Bibliográfico», in A Moderna História Econômica, ed. Carlos Manuel Peláez and Mircea Buescu, 203-12. Rio de Janeiro: APEC.

- (1978) [1960]. A Luta pela Industrialização do Brasil 1808-1930. Corpo e Alma, 5. São Paulo: Alfa Omega.

Marques, T. C. d. N. (1998), «O Setor Bancário Privado Carioca entre 1918 e 1945: Os Bancos Boavista e Português do Brasil - Um Estudo de Estratégias Empresariais», tese de mestrado. Rio de Janeiro: Universidade Federal de Rio de Janeiro.

Neuhaus, P. (1974), «A Monetary History of Brazil, 1900-1945», Ph. D. Diss, University of Chicago.

NoRTH, D. C. (1981), Structure and Change in Economic History, New York: Norton.

- (1990), Institutions, Institutional Change, and Economic Performance, Cambridge, Eng.: Cambridge University Press.

PaCheco, C. (1973), História do Banco do Brasil, 4 vols., Rio de Janeiro: Banco do Brasil.

Peláez, C. M. (1971a), «Análise Econômica de Programa Brasileiro de Sustentação do Café - 1906-1945: Teoria, Política e Medição», Revista Brasileira de Economia, 25(4, Oct.-Dec.): 5-211.

- (1971b), «As Conseqüências Econômicas da Ortodoxia Monetária, Cambial e Fiscal no Brasil entre 1889-1945», Revista Brasileira de Economia, 5(3, July-Sept.): 5-82.

- (1975), «The Establishment of Banking Institutions in a Backward Economy: Brazil, 1800-1850», Business History Review, 44(4, winter): 446-72.

- (1976a), «A Comparison of Long-Run Monetary Behavior and Institutions in Brazil, Europe and the United States», Journal of European Economic History, 5(2, fall): 439-50.

- (1976b), «The Theory and Reality of Imperialism in the Coffee Economy of Nineteenth-Century Brazil», Economic History Review, 2nd ser. 29(2, May): 276-90. 
Peláez, C. M., and Suzigan, W. (1976), História Monetária do Brasil: Análise da Politica, Comportamento e Instituiçōes Monetárias, Monografia (Instituto de Planejamento Econômico e Social. Instituto de Pesquisas), n. ${ }^{\circ} 23$, Rio de Janeiro: IPEA/INPES.

Platt, D. C. (1980), «Dependency in Nineteenth-Century Latin America: An Historian Objects», Latin American Research Review, 15(3): 113-30.

Prado Jr., C. (1993) [1945], História Econômica do Brasil, São Paulo: Brasilense.

Prado, L. C. T. (1991), «Commercial Capital, Domestic Market and Manufacturing in Imperial Brazil: The Failure of Brazilian Economic Development in the Nineteenth Century», Ph. D. Diss. University of London.

SaEs, F. A. d. (1986), Crédito e Bancos no Desenvolvimento da Economia Paulista: 1850-1930, Sāo Paulo: Instituto de Pesquisas Econônomicas.

- (1995), «Fontes para a História dos Bancos no Brasil (o Caso de São Paulo: 1850-1930)», América Latina in la Historia Económica: Boletín de Fuentes, 3 (January/June): 63-72.

Summerhill, W. R. (1995), «Railroads and the Brazilian Economy before 1914», Ph. D. Diss., Palo Alto CA: Stanford University.

SuzIGAN, W. (1986), Indústria Brasileira: Origem e Desenvolvimento, São Paulo: Brasiliense.

Suzigan, W., and SzmrecsánYI, T. (1996), «Os Investimentos Estrangeiros no Início da Industrializaçāo do Brasil», in História Econômica da Primeira República; Coletânea de Textos Apresentados no I Congresso Brasileiro de História Econômica, T. Szmrecsányi and Silva Sérgio, 261-83. Sāo Paulo: Hucitec.

TOPIK, S. (1987), The Political Economy of the Brazilian State, 1889-1930, Latin American monographs, Institute of Latin American Studies the University of Texas at Austin, n..$^{\circ}$, Austin: University of Texas Press.

TrINER, G. D. (1994), «Banking and Brazilian Economic Development: 1906-1930», Ph. D. Diss. Columbia University.

- (1996a), «British Banking in Brazil during the First Republic», in Anais, vol. 3; 129-51. II Congresso Brasileiro de História Econômica. Niterói: Associação Brasileira de Pesquisadores em História Econômica, October.

- (1996b), «The Formation of Modern Brazilian Banking, 1906-1930: Opportunities and Constraints Presented by the Public and Private Sectors», Joumal of Latin American Studies, 28 (Feb.): 49-74.

VERSIANI, F. R. (1980), «Industrialização e Economia de Exportação antes de 1914», Revista Brasileira de Economia, 34(1, Jan.-March): 3-40.

- (1984), «Before the Depression: Brazilian Industry in the 1920's», in Latin America in the 1930's: The Role of the Periphery in World Crisis, Rosemary Thorp, 163-87. Oxford: Macmillan Press.

Villela, A. V., and Suzigan, W. (1973), Política do Governo e Crescimento da Econômia Brasileira, 1889-1945, Instituto de Planejamento Econômico e Social, Instituto de Pesquisas, Monografia, n. ${ }^{\circ}$ 10. Rio de Janeiro: IPEA/INPES. 